\title{
Sale Force Automation Systems: The Correspondence Between The Perception Of Productivity Gains And The Perception Of Management Control Among Salespeople \\ David J. Faulds, (E-mail: djfaul01@gwise.louisville.edu), University of Louisville Jian Guan, (E-mail: jeff.guan@louisville.edu), University of Louisville Robert M. Barker, (E-mail: rmbarker@louisville.edu), University of Louisville Stephan F. Gohmann, (E-mail: sfgohm01@gwise.louisville.edu), University of Louisville
}

\begin{abstract}
Sales force automation (SFA) technologies have many apparent benefits, but the adoption of SFA systems often fails because the sales force holds poor perceptions of these technologies. Understanding how these perceptions affect adoption of SFA systems is important because negative perceptions held by the sales force can often adversely influence the successful adoption and implementation of such systems. This paper examines how the sales force's perceptions of productivity gains resulting from the adoption of an SFA system can be affected by their corresponding perception of the SFA system as a tool employed by upper-level management to more closely manage the activities of the sales force. The results are based on a national survey of 1,657 salespeople. The findings indicate a negative relationship between salespeople's perceptions of the potential gains associated with the adoption of an SFA system and their corresponding perception of the use of the system by upper-level management to more closely manage the activities of the sales force.
\end{abstract}

\section{INTRODUCTION}

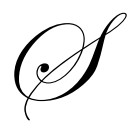

ales force automation (SFA) technologies provide automated sales support and integration of sales data with other corporate information. During the past decade, the use of SFA technologies has grown significantly (Blodgett, 1995; Schafer, 1997; Stein, 1998). SFA technologies are now considered to be a competitive imperative for many organizations. One of the important perceived benefits of SFA is improved productivity (Engle and Barnes, 2000; Pullig et al., 2002). Using SFA technologies may dramatically reduce the amount of time the sales force devotes to non-selling activities and therefore allow the sales force to focus on activities that directly lead to sales.

However, successful SFA implementation has remained elusive (Schafer, 1997; Stein, 1998). Recent research on SFA has examined various factors affecting its implementation (Keillor et al., 1997; Parthasarathy and Sohi, 1997; Engle and Barnes, 2000; Morgan and Inks, 2001; Effmeyer et al., 2001; Pullig et al., 2002; Speier and Venkatesh, 2002; Guan et al., 2004; Gohmann et al., 2005a, 2005b). Evidence has shown that positive perceptions of SFA technologies are critical to the successful adoption of such systems (Speier and Venkatesh, 2002). Negative perceptions of SFA as a tool to closely manage the sales force have been identified in the practitioner press as a major reason for user resistance to SFA implementation and the failure of such systems to achieve the expectations of management (Gondert, 1993; Stein, 1998). However, the academic literature offers little or no insight on this critical issue. 
The primary objective of this research is to examine the relationship between the perceptions of productivity gains held by salespeople and their perceptions of SFA systems as a tool used by upper-level management to more closely manage their sales activities. The study was conducted for the United States Army Recruiting Command (USAREC) to examine various issues relating to the adoption and implementation of the Army Recruiting Information Support System (ARISS). ARISS is the Army's equivalent of an SFA system and is used by the recruiting force to manage daily recruiting (sales) activities.

One of the important adoption issues identified by senior Army personnel was the critical relationship between the recruiting force's perception of productivity gains accruing from the adoption of ARISS and their corresponding perception of ARISS as a vehicle used by upper-level management to more closely manage their sales activities. Another objective of the Army was to assess the impact of system features such as the accuracy and quantity of information provided by ARISS as well as the adequacy of the training received by the sales force on their perceptions of the productivity gains accruing from the adoption of the system.

This investigation is the first known attempt to document in the academic literature what has previously been speculated on in the popular business press. The results of the study indicated a negative relationship between the recruiting force's perceptions of ARISS as a tool used by management to more closely direct their daily sales activities and their corresponding perceptions of the potential productivity gains associated with ARISS. The paper concludes by offering insights on how to address this undesirable outcome concerning to SFA implementation.

\section{RESEARCH CONCEPTUALIZATION}

Salespeople are often autonomous individuals who desire to work with little or no supervision (Jones et al., 2000; Wright, 2000). However, recent technological innovations are changing the autonomy inherent in the sales position. Since SFA systems allow for better tracking and monitoring of each member of the sales force (Rivers and Dart, 1999), salespeople may perceive these technologies as a tool used by upper-level managers to more closely manage their sales activities (Gondert, 1993; Stein, 1998).

From the viewpoint of sales management, knowledge of each sales person's activities may afford better allocation of resources and enhanced decision making. The potential return-on-investment in an SFA system is increased because it can be used to more closely monitor the activities of the sales force. However, from the point of view of salespeople, the "Big Brother" prospect of electronic monitoring can seriously erode their perception of autonomy. Hackman and Oldham (1980) find autonomy to be an important motivational element in any job. Thus, any perceived loss in autonomy due to the adoption of an SFA system may give users a negative perception of that system and reduce the potential productivity gains accruing from its adoption (Gondert, 1993). Since acceptance of technologies, including SFA technology, are affected by user perceptions (Speier and Venkatesh, 2002), the perception that the SFA system could lead to a loss in autonomy may be an important factor in the salesperson's acceptance of such technology.

Users' perceptions of the accuracy and quantity of information provided by an SFA system may also affect their perceptions of the potential productivity gains resulting from the adoption of such systems (Gohmann et al, 2005). Inaccurate information, the lack of information, or excessive information may diminish the potential productivity gains realized from the adoption of the system.

Training can also affect the perceived productivity gain of an SFA system. Training has been recognized as critical to the successful acceptance of SFA (Rasmussen, 1999; Erffmeyer and Johnson, 2001; Ahearne et al, 2005). If salespeople think that their training was adequate, they are more likely to be able to master the system and take advantage of its productivity-increasing attributes. Morgan and Inks (2001) found that salespeople are more likely to accept SFA if they perceive that their training has been adequate.

One of the main reasons for SFA implementation is the mounting pressure for sales management to increase sales productivity (Johnston, 1995). SFA systems allow the sales force to use information technology for the automation and standardization of selling and administrative activities (Morgan and Inks, 2001). One of the major 
goals of sales managers and salespeople in using SFA is to improve the efficiency of the selling process (Erffmeyer and Johnson, 2001). Given that SFA can improve productivity (Engle and Barnes, 2000; Pullig et al., 2002), it can potentially increase commissions for the sales force and generate greater profits for the company. The perception of a gain in sales productivity through the use of SFA technologies should lead to increased acceptance of the SFA system by both the sales force and management. Therefore, the influence of the sales force's perception of SFA technologies as a management tool to more closely manage the sales force on the corresponding perception of the potential productivity gains from the adoption of these systems is a critical research issue.

\section{RESEARCH SETTING}

The data for this study were collected in a survey that focused on various issues relating to the adoption and implementation of the Army Recruiting Information Support System--ARISS. ARISS was developed during the 1990s to serve as USAREC's SFA system and was deployed across the recruiting command in 2000.

The recruiting command receives over 20 million contacts per year, and ARISS offers USAREC an automated method to manage these contacts. ARISS provides critical recruiting (sales) information on potential recruits and sales support materials used by the recruiting force in conducting their daily sales activities. In addition, ARISS provides upper-level management with information necessary to monitor, track, and manage the activities of the recruiting force.

USAREC's organizational structure is divided into five brigades, 41 battalions, 270 companies, and approximately 1,600 recruiting stations (RSID) that span the entire United States. The RSID territories are distinct geographical entities, equivalent to sales territories in the private sector, and represent the foundation of USAREC's organizational structure (see Figure 1 for a map of the five brigades). The individual recruiting stations are managed by a station commander who serves as a frontline sales manager, and recruiters perform ubiquitous sales activities such as prospecting, conducting sales calls, handling questions and complaint management, closing sales contracts, and follow-up activities.

One of the benefits of surveying Army recruiters is that individual and organizational factors that could influence the perception of productivity gains realized from the adoption of ARISS are held constant. For example, Army recruiters receive the same sales training at the same Army installation from the same sales trainers. In addition, Army recruiters fall into approximately the same age range and have comparable levels of formal education. Organizational factors, such as operating procedures for individual recruiting stations, methods of compensation, advertising and promotional campaigns, and personnel policies are all standardized. This environment is ideal for examining the sales force's perceptions of productivity gains resulting from the adoption of an SFA system as well as the sale force's corresponding perceptions of upper-level management's use of the system to more closely manage salespeople's activities.

\section{METHODOLOGY}

To address the primary objective of the research, a survey instrument was developed and administered to recruiting station commanders and recruiters. The development of the instrument started with an extensive review of academic studies and industry and trade literature. This review served as a guide for conducting a series of depth interviews with recruiting station commanders and recruiters to obtain their thoughts and observations on the primary issues involved in the research objective. Based on the information gleaned from the literature review and the depth interviews, the survey instrument was developed. After careful pre-testing, the instrument was administered across the entire recruiting command. Approximately 3,350 recruiting personnel received the survey and 1,657 returned the completed questionnaire, resulting in a response rate of 49 percent.

To assess non-response error, a trend analysis was conducted that involved dividing the respondents into three groups: early respondents, intermediate respondents, and late respondents. A chi-square contingency table analysis was performed across the three groups comparing their responses to each statement contained in the survey. 
The results of this analysis indicated that the three groups were homogeneous with respect to their responses to the statements.

The respondents were asked to respond to statements about their perceptions of productivity improvement resulting from the adoption of ARISS and their corresponding perceptions of how upper-level management could use ARISS "to more closely manage" their daily sales activities. The questions used a 7-point Likert-type scale, ranging from "strongly disagree" to "strongly agree" (with "strongly disagree" equal to 1 and "strongly agree" equal to 7.)

Two questions focused on perceptions of productivity--"The system has made me more productive" and "If I stopped using the system, my productivity would remain the same or increase." These questions served as the primary dependent variables. The first dependent variable is based on a 7-point Likert-type scale and the second was coded using a dummy variable, with 1 indicating that productivity would remain the same or increase and 0 indicating that productivity would decrease. A logistic regression was used for this dependent variable.

The study examined two groups--recruiters and station commanders. The recruiters are salespeople. Station commanders may perform both sales activities and management functions. In the management role, the station commanders use ARISS to retrieve information about each recruiter's sales activities and to produce reports for higher-level management.

Two questions measured the perceptions of recruiters concerning upper-level management's use of ARISS "to more closely manage" the activities of recruiters--"By using ARISS to closely manage recruiting stations, upperlevel management (company-battalion-brigade-USAREC personnel) can improve the productivity of individual recruiting stations;" and "One purpose of the system is to allow upper-level management to more closely manage the sales personnel."

Several additional independent variables were included in the study. These variables included recruiters' perceptions of the accuracy and quantity of the information provided in ARISS and their perceptions of the usefulness of the training they received for ARISS.

All respondents were asked whether "The quantity of information provided by the system for each potential lead should be increased, decreased, or remain the same." Relative to respondents who think that the information should remain the same, it is likely that those who think it should be increased or decreased will be less likely to perceive that the system makes them more productive. Two dummy variables included for this statement-- "increase quantity of information" and "decrease quantity of information"-- were coded as 1, and "the amount of information should remain the same" was the comparison response. Recruiters were also asked to rate, on a 7-point Likert-type scale, their perception of the adequacy of the training they received.

Information on job-related characteristics of the recruiters, such as sales experience, the recruiter's military occupational specialty (MOS), and the number of hours a week the recruiter worked, was also collected. Finally, the number of months the recruiting station met its recruiting goals and the length of time the station commander served in that location were recorded.

Cronback's coefficient alpha was used to calculate the reliability of the instrument. This method yielded a coefficient of 0.86 , suggesting high reliability for the measures used in the survey.

The data collected from the survey provided an opportunity to test the hypothesis that salespeople's perceptions of productivity gains resulting from the adoption of ARISS may be negatively related to their corresponding perceptions of upper-level management's use of the system "to more closely manage" the sales personnel. To test this hypothesis, the following regression equation was estimated.

$\mathrm{Y}_{1}=\mathrm{B}_{0}+\mathrm{B}_{1} \mathrm{X}_{1}+\mathrm{B}_{2} \mathrm{X}_{2}+\mathrm{B}_{3} \mathrm{X}_{3}+\mathrm{B}_{4} \mathrm{X}_{4}+\mathrm{B}_{5} \mathrm{X}_{5}+\varepsilon$

where:

$\mathrm{Y}_{1}=$ The system makes me more productive 
$\mathrm{X}_{1}=$ One purpose of the system is to allow upper-level management to more closely manage the sales personnel

$\mathrm{X}_{2}=\mathrm{By}$ using the system to closely manage the recruiting stations, upper-level management can improve the productivity of individual recruiting stations

$\mathrm{X}_{3}=$ Information is accurate

$\mathrm{X}_{4}=$ Training was helpful

$\mathrm{X}_{5}=$ Dummy variable coded 0 for quantity of information should be decreased and 1 for quantity of information should be increased.

$\mathrm{B}_{0}-\mathrm{B}_{5}$ are the parameters to be estimated and

$\varepsilon$ is the an error term.

For the first model the dependent variable, $\mathrm{Y}$, is a 7-point Likert scale variable "The system makes me more productive," $\varepsilon \sim \mathrm{N}(0,1)$ and ordinary least squares is applied. A priori, we expect $\mathrm{B}_{1}$ to be negative and $\mathrm{B}_{2}, \mathrm{~B}_{3}, \mathrm{~B}_{4}$, and $\mathrm{B}_{5}$ to be positive.

The second model uses a dichotomous dependent variable, $\mathrm{Y}_{2}$, equal to 1 if the respondent answered yes to "If I stopped using the system, my productivity would remain the same or increase", otherwise the dependent variable equals 0 . For a dichotomous dependent variable ordinary least squares is inappropriate. Instead a logit model was used to estimate the probability that the dependent variable equals 1 . The independent variables are the same as in equation (1) and the second model is

$\operatorname{Prob}\left(Y_{2}=1 \mid X\right)=f\left(X_{1}, X_{2}, X_{3}, X_{4}, X_{5}, \gamma\right)$

For equation (2), the independent variables $\mathrm{X}_{1}, \mathrm{X}_{2}, \mathrm{X}_{3}, \mathrm{X}_{4}, \mathrm{X}_{5}$ are defined as above. In this model the error term, $\gamma$, is from the logit distribution function. The model was estimated using SAS "proc logistic."

\section{RESULTS AND DISCUSSION}

Table 1 shows the summary statistics for the variables in the study for recruiters and station commanders. A Likert scale value of 4 is neutral; therefore, a mean less than 4 indicates that the respondents on average did not agree with the statement. Thus, for the first dependent variable--"The system makes me more productive"--the average of 3.4 for the recruiters and 3.1 for the station commanders indicates that the two groups did not perceive that the system improved their productivity. Likewise, for the second dependent variable--"If I stopped using the system, my productivity would remain the same or increase"--over $85 \%$ of the respondents (recruiters and station commanders) thought that their productivity would increase or remain the same if they stopped using the system. This result implies that most respondents do not perceive productivity gains resulting from the adoption of ARISS.

Both groups tended to perceive that the system was installed to allow upper-level management "to more closely manage" their sales activities, but neither group thought that upper- level management would be able to increase productivity using the system in this fashion. The groups were evenly split on the information accuracy statement, and they tended to agree that their training was helpful. A majority of the recruiters $(65 \%)$ and station commanders (58\%) thought that the quantity of information should be increased, with less than $10 \%$ of either group indicating that the quantity of information should be decreased. The results clearly indicate that the respondents perceived the system to be a tool used by upper-level management "to more closely manage" their sales activities. However, the respondents also indicated that the use of this system "to more closely manage" their sales activities would not lead to a corresponding increase in sales productivity.

Table 1 reports job-related characteristics for the sample. Over $90 \%$ of the recruiters and station commanders were full-time recruiters with a military specialty (MOS) in this area. Most of the recruiters (67\%) had less than 2 years of experience, and $41 \%$ of the station commanders had been assigned to their station for less than 6 months. In addition to their management tasks, half of the station commanders performed recruiting activities.

Table 2 shows the regression results for the dependent variable "The system has made me more productive." The results indicate that those individuals who perceived that the system was used by upper-level management "to 
more closely manage" their sales activities were less likely to perceive that the system would increase their productivity. The second independent variable, however, indicated that "By using the system to more closely manage recruiting stations, upper- level management can improve the productivity of individual recruiting stations" revealed a slight positive impact on the dependent variable--"The system makes me more productive." This relationship was found to hold for both recruiters and station commanders. The pattern of results indicates that salespeople's perceptions of the use of an SFA system by upper-level management "to more closely manage" their sales activities may lead to a corresponding negative perception of the potential gains in productivity accruing from the adoption of such a system.

Table 2 also shows that both recruiters and station commanders who perceived the information provided by the system was accurate were also more likely to think the system made them more productive. On the other hand, recruiters and station commanders who thought the quantity of information should be decreased were less likely to perceive enhancements in productivity. A positive relationship exists between the perception of the adequacy of training and the perception that the system would increase productivity. These results are consistent with those previously reported in the literature (Morgan and Inks, 2001; Ahearne et al., 2005).

The results describing the impact of job-related characteristics on the dependent variable "The system makes me more productive" are found in the second half of Table 2. For recruiters, the only statistically significant jobrelated characteristic is the number of years of job experience. Recruiters and station commanders designated as career recruiters (MOS) had negative perceptions of the ability of the system to improve their productivity. Another noteworthy characteristic was that station commanders from productive recruiting stations were less likely to perceive productivity gains resulting from the adoption of the system.

Table 3 shows the logistic regression results for the dependent variable "If I stopped using the system, my productivity would remain the same or increase." Similar to the results in Table 2, the results in Table 3 indicate that those individuals who thought that the system was used by upper-level management "to more closely manage" their sales activities were also less likely to believe that the system would improve their productivity. Similar results are also found for the second independent variable--"By using the system to more closely manage recruiting stations, upper-level management can improve the productivity of individual recruiting stations." The results for the perceived adequacy of training and the quantity of information provided by the system were also found to be similar to those reported in Table 2.

For the job-related characteristics, the recruiters and station commanders who were most productive (as determined by the number of months the station met its recruiting goals) believed that their productivity would increase if they stopped using the system. The results for the remaining job-related characteristics are similar to those reported in Table 2 .

\section{CONCLUSIONS}

The results of this research support the conclusion that perceived productivity gains accruing from the adoption of an SFA system are negatively related to the sales forces corresponding perception that the system may be used by upper-level management to more closely manage the activities of the sales force. This finding is consistent with the discussion reported in the popular business press. The survey results also indicated that the sales force believed that upper-level management could not improve sales productivity by using the system to more closely manage their activities.

These results are significant because they demonstrate how the primary motive for the adoption of an SFA system, productivity gains, can be eroded by the sales force's perceptions of the intended use of the system by upperlevel management. Therefore, managing the perceptions of the sales force relating to management's intended use of the adopted SFA technology is critical to the successful adoption of the system.

Three important implications stem from this research. First, the process of managing perceptions should begin prior to adopting the SFA system. An important element of this process entails communicating with the sales 
force and soliciting their input regarding the needs and requirements of the proposed SFA system prior to its design and implementation. Such communication should foster the perception of involvement and ownership among the salespeople.

Second, the organization must allow for robust and rigorous training of the sales force. This training should emphasize the positive aspects of the system. Finally, the organization should continuously promote the benefits of the system and work to enhance the perception of the system as a support tool for the sales force.

Given the unique environment from which the sample was drawn, the United States Army Recruiting Command, future research should extend the issues addressed in this study to other organizational settings. In light of the tremendous costs of adopting and implementing SFA technology, this stream of research may offer significant benefits to both private and public sector organizations contemplating the adoption of these technologies.

\section{REFERENCES}

1. Ahearne, Michael, Jelinek, Ronald, and Rapp, Adam, Moving Beyond the Direct Effect of SFA Adoption on Salesperson Performance: Training and Support as Key Moderating Factors, Industrial Marketing Management, Vol. 34, Iss. 4, p. 379- 388, 2005.

2. Blodgett, Mindy, Vendor Tries to Simplify Sales Force Automation, Computerworld, Vol. 30, No. 1, pp. 6262, 1995.

3. Engle, Robert L. and Barnes, Michael L., Sales Force Automation Usage, Effectiveness, and Cost-Benefit in Germany, England and the United States, Journal of Business \& Industrial Marketing, Vol.15, No. 4, pp. 216-241, 2000.

4. Erffmeyer, Robert C. and Johnson, Dale A., An Exploratory Study of Sales Force Automation Practices: Expectations and Realities, Journal of Personal Selling \& Sales Management, Vol. XXI, No. 2, pp. 167-175, 2001.

5. Gohmann, Stephan F., Faulds, David J, Guan, Jian, and Barker, Robert M., Sales Force Automation, Information Accuracy and User Satisfaction, Journal of Business \& Industrial Marketing, Vol. 20, Iss. 1; p. 23-32, 2005.

6. Gohmann, Stephan F., Guan, Jian, Barker, Robert M., and Faulds, David J., Perceptions of Sales Force Automation: Differences between Sales Force and Management, Industrial Marketing Management, Vol. 34, Iss. 4, pp. 337-343, 2005.

7. Gondert, Stephen, Automation: The 10 Biggest Mistakes of SFA (and how to avoid them), Sales and Marketing Management, Vol. 145, No. 2, pp. 52-57, 1993.

8. Guan, Jian, Barker, Robert M., Faulds, David J., and Gohmann, Stephan F., Sales Force Automation Acceptance: An Exploratory Study of the Role of Job Experience, Journal of Applied Business Research, Vol. 30, No. 3, pp. 103-114, 2004.

9. Hackman, R. and Oldham, G., Work Redesign. Reading, MA, Addison-Wesley Publishing, 1980.

10. Honeycutt, Earl D., Jr., Thelen, Tanya, Thelen, Shawn T., and Hodge, Sharon K., Impediments to Sales Force Automation, Industrial Marketing Management, Vol. 34, Issue 4, pp. 313- 322, 2005.

11. Johnston, Wesley J., Editorial, The Journal of Business \& Industrial Marketing, Vol. 10, No. 2, pp. 4-6, 1995.

12. Jones, Eli, Roberts, James A., and Chonko, Lawrence B., Motivating Sales Entrepreneurs to Change: A Conceptual Framework of Factors Leading to Successful Change Management Initiatives in Sales Organizations, Spring, pp. 37-49, 2000.

13. Keillor, Bruce D., Bashaw, R. Edward, and Pettijohn, Charles E., Sales Force Automation Issue Prior to Implementation: The Relationship between Attitudes Toward Technology, Experience, and Productivity, The Journal of Business \& Industrial Marketing, Vol. 12, No. 3, pp. 209-219, 1997.

14. Morgan, Amy J. and Inks, Scott A., Technology and the Sales Force: Increasing Acceptance of Sales Force Automation, Industrial Marketing Management, Vol. 30, No. 5, pp. 463-472, 2001.

15. Parthasarathy, Madhavan and Sohi, Ravipreet S., Sales Force Automation and the Adoption of Technological Innovations by Salespeople: Theory and Implications, Journal of Business \& Industrial Marketing, Vol. 12, No. 3, pp. 196-208, 1997. 
16. Pullig, Chris, Maxham, James G. III, and Hair, Joseph F., Jr., Sales Force Automation Systems: An Exploratory Examination of Organizational Factors Associated with Effective Implementation and Sales Force Productivity, Journal of Business Research, Vol. 55, pp. 401-415, 2002.

17. Rasmussen, E., Get Plugged In: The 5 Steps to Successful Sales Force Automation, Sales and Marketing Management, Vol. 151, No. 3, pp. 24-40, 1999.

18. Rivers, L. Mark and Dart, Jack, The Acquisition and Use of Sales Force Automation by Mid-Sized Manufacturers. Journal of Personal Selling \& Sales Management, Vol. XIX, No. 2, Spring, pp. 59-73, 1999.

19. Schafer, S., Supercharged sell. Inc., Technology Supplement, Vol. 19, pp. 42-52, June 17, 1997.

20. Schillewaert, Niels, Ahearne, Michael J., Frambach, Ruud, T., and Moenaert, Rudy K., The Adoption of Information Technology in the Sales Force, Journal of Applied Business Research, Vol. 30, No. 3, pp. 323336, 2004.

21. Speier, Cheri and Venkatesh, Viswanath, The Hidden Minefields in the Adoption of Sales Force Automation Technologies, Journal of Marketing, Vol. 66, pp. 98-111, July 2002.

22. Stein, Tom, Software for the Hard Sell--By Adding Functionality, Sales Force Automation Systems are Overcoming a Bad Reputation. InformationWeek, Vol. 671, pp. 18-19, March 1998.

23. Wang, Guangping and Netemeyer, Richard G., The Effects of Job Autonomy, Customer Demandingness, and Trait Competitiveness on Salesperson Learning, Self-Efficacy, and Performance, Journal of the Academy of Marketing Science, Vol. 30, No. 3, p. 217-228, 2002.

24. Wright, Robert F., Strategies for Avoiding the Micro Management Trap, Management Decision, Vol. 38, No. 5,2000 .

Figure 1: United States Army Recruiting Command: Location Of Brigades

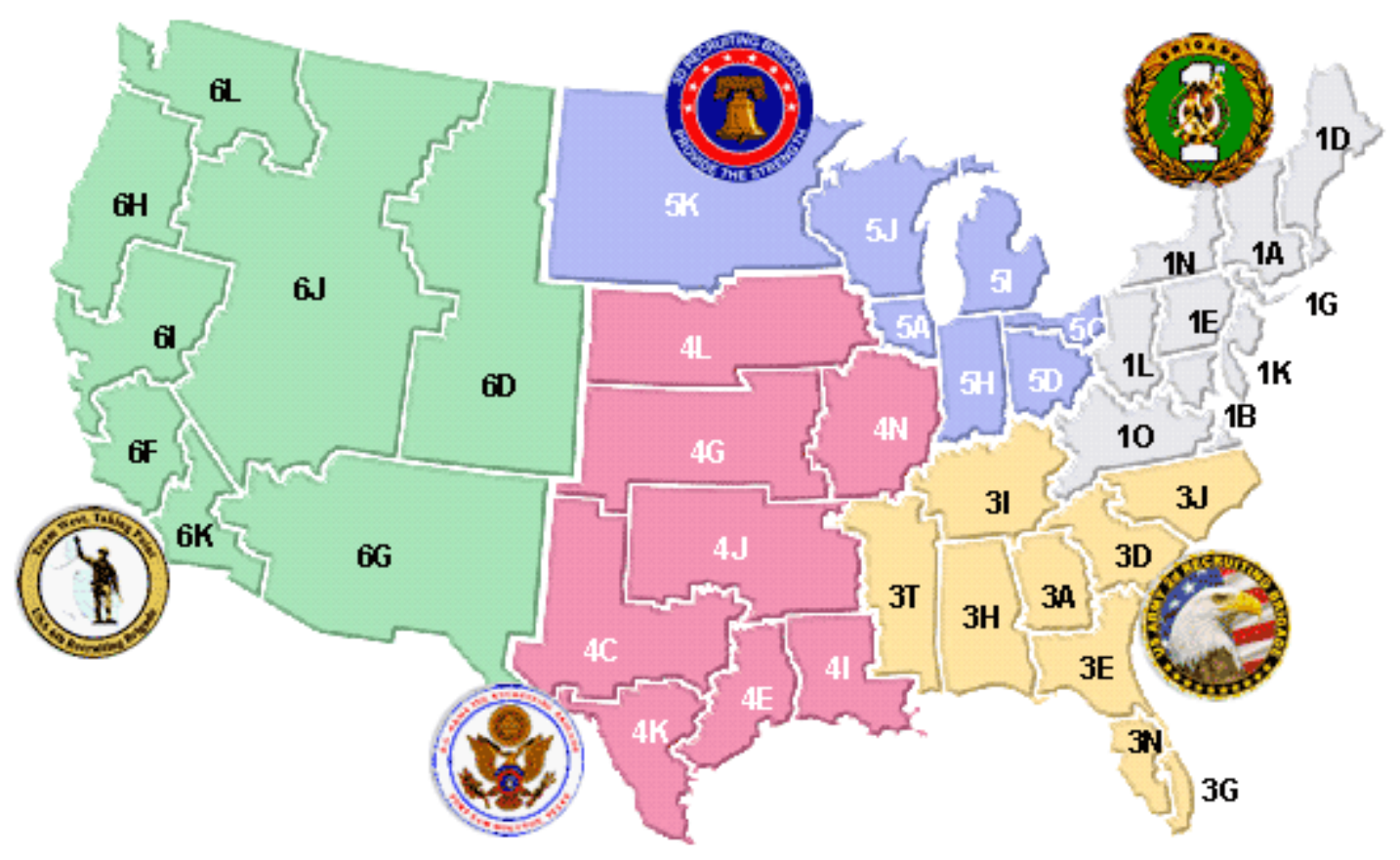


Table 1: Summary Statistics

\begin{tabular}{|c|c|c|c|c|}
\hline \multirow{2}{*}{$\begin{array}{l}\text { Variables } \\
\text { Dependent Variables: }\end{array}$} & \multicolumn{2}{|c|}{ Recruiter } & \multicolumn{2}{|c|}{ Station Commander } \\
\hline & Mean & $\begin{array}{l}\text { Standard } \\
\text { Deviation }\end{array}$ & Mean & $\begin{array}{l}\text { Standard } \\
\text { Deviation }\end{array}$ \\
\hline The system makes me more productive & 3.42 & 1.48 & 3.17 & 1.48 \\
\hline $\begin{array}{l}\text { If I stopped using the system, my productivity would } \\
\text { remain the same or increase }\end{array}$ & 0.85 & 0.35 & 0.89 & 0.32 \\
\hline \multicolumn{5}{|l|}{ System Characteristics: } \\
\hline $\begin{array}{l}\text { One purpose of the system is to allow upper level } \\
\text { management to more closely manage the sales } \\
\text { personnel }\end{array}$ & 5.503 & 1.38 & 5.51 & 1.37 \\
\hline $\begin{array}{l}\text { By using the system to closely manage recruiting } \\
\text { stations, upper level management can improve the } \\
\text { productivity of individual recruiting stations }\end{array}$ & 3.68 & 1.62 & 3.56 & 1.63 \\
\hline Information is accurate & 4.05 & 1.56 & 4.07 & 1.53 \\
\hline Training was helpful & 4.41 & 1.69 & 4.17 & 1.69 \\
\hline Quantity of Information should be increased & 0.65 & 0.48 & 0.58 & 0.49 \\
\hline Quantity of Information should be decreased & 0.06 & 0.24 & 0.10 & 0.29 \\
\hline \multicolumn{5}{|l|}{ Job-Related Characteristics: } \\
\hline MOS Recruiter & 0.94 & 0.24 & 0.91 & 0.29 \\
\hline Works $>60$ hours/week & 0.66 & 0.47 & 0.69 & 0.46 \\
\hline Experience $<2$ years & 0.67 & 0.47 & & \\
\hline Commanded station $<6$ months & & & 0.41 & 0.49 \\
\hline On Production Commander & & & 0.50 & 0.50 \\
\hline Months Station Met mission & 3.39 & 2.89 & 3.74 & 2.93 \\
\hline Sample Size & 1,657 & & 1,125 & \\
\hline
\end{tabular}

Table 2: Regression For "The System Makes Me More Productive"

\begin{tabular}{|l|c|c|}
\hline \multicolumn{1}{|c|}{ Variables } & Recruiters & $\begin{array}{c}\text { Station } \\
\text { Commanders }\end{array}$ \\
\hline System Variables: & Beta & Beta \\
\hline $\begin{array}{l}\text { One purpose of the system is to allow upper-level management to more closely } \\
\text { manage the sales personnel }\end{array}$ & -0.019 & $-0.049 \mathbf{c}$ \\
$(0.021)$ & $0.027)$ \\
\hline By using the system to closely manage recruiting stations, upper- level & $0.302 \mathbf{a}$ & $0.310 \mathbf{a}$ \\
management can improve the productivity of individual recruiting stations & $(0.019)$ & $(0.024)$ \\
\hline Information is accurate & $0.264 \mathbf{a}$ & $0.197 \mathbf{a}$ \\
& $(0.020)$ & $(0.026)$ \\
\hline Training was helpful & $0.160 \mathbf{a}$ & $0.176 \mathbf{a}$ \\
& $(0.019)$ & $(0.023)$ \\
\hline Quantity of information should be increased & 0.043 & 0.005 \\
& $(0.066)$ & $(0.082)$ \\
\hline Quantity of information should be decreased & $-0.306 \mathbf{b}$ & $-0.412 \mathbf{a}$ \\
& $(0.133)$ & $(0.137)$ \\
\hline Job-Related Characteristics: & & $-0.402 \mathbf{a}$ \\
\hline MOS Recruiter & -0.097 & $(0.132)$ \\
\hline Works >60 hours/week & $(0.119)$ & -0.084 \\
& -0.025 & $(0.080)$ \\
\hline Experience < 2 years & $(0.062)$ & $0.369 \mathbf{a}$ \\
& $(0.062)$ & \\
\hline Commanded station <6 months & & $(0.077)$ \\
\hline On Production Commander & & 0.101 \\
& & $(0.076)$ \\
\hline
\end{tabular}




\begin{tabular}{|l|c|c|}
\hline Months met mission & -0.007 & $-0.030 \mathbf{b}$ \\
& $(0.010)$ & $(0.013)$ \\
\hline Intercept & $0.504 \mathbf{b}$ & $1.309 \mathbf{a}$ \\
& $(0.208)$ & $(0.255)$ \\
\hline Adjusted R-Square & 0.359 & 0.312 \\
\hline
\end{tabular}

$\begin{array}{ll}\text { a } & \text { p-value }<0.01 \\ \text { b } & \text { p-value }<0.05 \\ \text { c } & \text { p-value }<0.10\end{array}$

Table 3: Logistic Regression For "If I Stopped Using The System, My Productivity Would Remain The Same Or Increase"

\begin{tabular}{|c|c|c|}
\hline Variables & Recruiters & $\begin{array}{c}\text { Station } \\
\text { Commanders }\end{array}$ \\
\hline System Variables: & Beta & Beta \\
\hline $\begin{array}{l}\text { One purpose of the system is to allow upper-level management to more closely } \\
\text { manage the sales personnel }\end{array}$ & $\begin{array}{c}-0.149 \mathbf{b} \\
(0.059) \\
\end{array}$ & $\begin{array}{l}-0.089 \\
(0.079)\end{array}$ \\
\hline $\begin{array}{l}\text { By using the system to closely manage recruiting stations, upper- level } \\
\text { management can improve the productivity of individual recruiting stations }\end{array}$ & $\begin{array}{l}0.339 \mathbf{a} \\
(0.055) \\
\end{array}$ & $\begin{array}{r}0.373 \mathbf{a} \\
(0.070) \\
\end{array}$ \\
\hline Information is accurate & $\begin{array}{l}0.364 \mathbf{a} \\
(0.055)\end{array}$ & $\begin{array}{l}0.240 \mathbf{a} \\
(0.074) \\
\end{array}$ \\
\hline Training was helpful & $\begin{array}{l}0.166 \mathbf{a} \\
(0.054)\end{array}$ & $\begin{array}{l}0.144 \mathbf{b} \\
(0.069)\end{array}$ \\
\hline Quantity of information should be increased & $\begin{array}{l}0.282 \mathbf{c} \\
(0.163)\end{array}$ & $\begin{array}{c}0.097 \\
(0.214)\end{array}$ \\
\hline Quantity of information should be decreased & $\begin{array}{l}-0.980 \mathbf{c} \\
(0.550)\end{array}$ & $\begin{array}{l}-0.263 \\
(0.438) \\
\end{array}$ \\
\hline \multicolumn{3}{|l|}{ Job Related Characteristics: } \\
\hline MOS Recruiter & $\begin{array}{c}0.009 \\
(0.302)\end{array}$ & $\begin{array}{c}-0.703 \mathbf{b} \\
(0.292)\end{array}$ \\
\hline Works $>60$ hours/week & $\begin{array}{l}-0.190 \\
(0.152)\end{array}$ & $\begin{array}{l}0.382 \mathbf{c} \\
(0.228)\end{array}$ \\
\hline Experience $<2$ years & $\begin{array}{l}0.697 \mathbf{a} \\
(0.177) \\
\end{array}$ & \\
\hline Commanded station $<6$ months & & $\begin{array}{c}-0.164 \\
(0.208) \\
\end{array}$ \\
\hline On Production Commander & & $\begin{array}{l}-0.112 \\
(0.202)\end{array}$ \\
\hline Months met mission & $\begin{array}{l}-0.034 \\
(0.026)\end{array}$ & $\begin{array}{c}-0.107 \mathbf{a} \\
(0.038)\end{array}$ \\
\hline Intercept & $\begin{array}{c}-5.149 \mathbf{a} \\
(0.578) \\
\end{array}$ & $\begin{array}{c}-3.942 \mathbf{a} \\
(0.704) \\
\end{array}$ \\
\hline Likelihood Ratio & $185.3 \mathbf{a}$ & $89.5 \mathbf{a}$ \\
\hline
\end{tabular}

$\begin{array}{ll}\text { a } & \text { p-value }<0.01 \\ \text { b } & \text { p-value }<0.05 \\ \text { c } & \text { p-value }<0.10\end{array}$

\section{Endnotes}

\footnotetext{
i The concept "to more closely manage" was measured using a unidimensional scale. This approach was adopted because of the highly standardized work environment in which the sales force operated. Discussions with USAREC personnel and extensive depth interviews with station commanders and recruiters supported the use of a single item to measure this concept.
} 